\title{
Tanggungjawab Promotor Perseroan Terbatas Terhadap Kontrak Pra Inkorporasi di Indonesia
}

\author{
Xavier Nugraha dan Ave Maria Frisa Katherina \\ xavier.nugraha-2015@fh.unair.ac.id \\ Universitas Airlangga
}

\begin{abstract}
Ratification of a legal entity based on the issuance of a Decree of the Minister of Law and Human Rights requires a process that is not brief. Meanwhile, corporation which has not been ratified as a legal entity does not rule out the possibility that the promotors of corporation will carry out legal actions in the name of corporation. This journal aims to provide an explanation of the extent to which the liability of corporation and promoters on contracts made before corporation becomes a legal entity. The research methods in this study are conceptual approach and statute approach. Who is responsible for pre-incorporation contract? From this journal, it will be known that liability which appears from pre-incorporation contract lies on promotor before corporation becomes a legal entity, but when the legal action has been approved by the General Meeting of Shareholders or has been stated in the deed of establishment, it will become corporate's actions, therefore the liability is also attached.
\end{abstract}

Keywords: Liability; Corporation; Promotors; Pre-Incorporation Contract.

\begin{abstract}
Abstrak
Pengesahan badan hukum berdasarkan dikeluarkannya Keputusan Menteri Hukum dan Hak Asasi Manusia membutuhkan proses yang tidak sebentar. Sementara itu, belum disahkannya PT sebagai badan hukum tidak menutup kemungkinan bahwa para pendiri PT akan melakukan perbuatan hukum atas nama PT yang sejatinya belum berbadan hukum. Penelitian ini bertujuan untuk memberikan penjelasan mengenai sejauh mana pertanggungjawaban PT dan para promotor PT terhadap kontrak yang dibuat sebelum PT menjadi badan hukum. Penelitian ini menggunakan metode penelitian conceptual approach dan statute approach. Siapakah yang harus bertanggung jawab ketika kontrak dibuat dalam tahap prainkorporasi? Dalam penelitian ini akan diketahui bahwa hakikatnya sebelum PT berbadan hukum tanggung jawab terletak pada pendiri PT, namun ketika perbuatan hukum itu telah disetujui oleh RUPS atau telah tertera dalam akta pendirian, maka perbuatan pendiri tersebut menjadi perbuatan PT, sehingga tanggung jawab melekat pada PT.
\end{abstract}

Kata Kunci: Tanggung Jawab; Perseroan Terbatas; Pendiri; Kontrak Prainkorporasi.

\section{Pendahuluan}

Perkembangan dunia usaha dewasa ini mengalami pertumbuhan yang sangat pesat. Setiap orang dalam mengembangkan suatu usaha tertentu selalu membutuhkan suatu wadah. Wadah untuk mengembangkan kegiatan bisnis tersebut umumya terdiri dari 2 (dua) bentuk, yaitu badan usaha yang berbentuk bukan badan hukum, 
maupun yang berbentuk badan hukum. ${ }^{1}$ Badan usaha yang berbentuk bukan badan hukum antara lain Usaha Dagang, Firma, Maatschap, dan Perseroan Komanditer. Kemudian badan usaha yang berbentuk badan hukum antara lain Perseroan Terbatas (selanjutnya disebut PT), Yayasan, Koperasi, Perkumpulan yang berbadan hukum, dan badan hukum lainnya. ${ }^{2}$

Dewasa ini, badan usaha yang paling banyak dipilihuntukmengembangangkan suatu kegiatan usaha tertentu adalah PT, bahkan banyak badan usaha yang dulunya tidak berbentuk PT, banyak yang beralih ke bentuk PT. Karakteristik PT secara umum antara lain adalah: ${ }^{3}$

1. Memiliki status hukum tersendiri, yaitu sebagai suatu badan hukum, yaitu subyek hukum artificial, yang sengaja diciptakan oleh hukum untuk membantu kegiatan perekonomian, yang dipersamakan dengan individu manusia, orang-perorangan;

2. Memiliki harta kekayaan sendiri yang dicatatkan atas namanya sendiri, dan pertanggungjawaban sendiri atas setiap tindakan, perbuatan, termasuk perjanjian yang dibuat. Ini berarti perseroan dapat mengikatkan dirinya dalam satu atau lebih perikatan, yang berarti menjadikan perseroan sebagai subyek hukum mandiri yang memiliki kapasitas dan kewenangan untuk dapat menggugat dan digugat di hadapan pengadilan;

3. Tidak lagi membebankan tanggungjawabnya kepada pendiri, atau pemegang sahamnya, melainkan hanya untuk dan atas nama dirinya sendiri, untuk kerugian dan kepentingan dirinya sendiri;

4. Kepemilikannya tidak digantungkan pada orang perorangan tertentu, yang merupakan pendiri atau pemegang sahamnya. Setiap saat saham perseroan dapat dialihkan kepada siapapun juga menurut ketentuan yang diatur dalam Anggaran Dasar dan Undang-Undang yang berlaku pada suatu waktu tertentu;

5. Keberadaannya tidak dibatasi jangka waktunya dan tidak lagi dihubungkan dengan eksistensi dari pemegang sahamnya;

6. Pertanggungjawaban yang mutlak terbatas, selama dan sepanjang para pengurus (direksi), dewan komisaris dan atau pemegang saham tidak melakukan pelanggaran terhadap hal-hal yang tidak boleh dilakukan.

Menurut Normin S Pakpahan, beberapa beberapa pertimbangan PT dipilh sebagai bentuk badan hukum usaha dalam melakukan kegiatan bisnis, antara lain

\footnotetext{
1 Yoahana, 'Tanggung Jawab Hukum Atas Bentuk Usaha Badan Hukum Dan Bentuk Usaha Non Badan Hukum' (2015) 8 Mecatoria.[47].

2 Nunuk Listyowati,'Tanggung Jawab Hukum Perseroan Terbatas Yang Belum Berstatus Badan Hukum'(2015) 1 Spirit Pro Patria.[25].

3 Gunawan Widjaja, Risiko Hukum Pemilik, Direksi \& Komisaris PT, Cetakan Pertama (Forum Sahabat 2008).[11-12].
} 
adalah: ${ }^{4}$

1. Kedudukan yang mandiri dari perseroan terbatas. Perseroan Terbatas oleh hukum dipandang berdiri sendiri, otonom terlepas dari orang perorangan yang berada dalam PT tersebut, sehingga oleh hukum perbuatan PT tersebut dipandang sematamata sebagai perbuatan PT itu sendiri.

2. Pertanggungjawaban yang terbatas Pertanggungjawaban dibebankan kepada harta. kekayaan yang terhimpun dalam asosiasi. Ini berarti beban resiko sebagai suatu kegiatan ekonomi terbatas pada kekayan perseroan.

3. Adanya mobilitas atas hak penyertaan. Dampak positif dari konstruksi ini adalah terjaganya keutuhan modal yang telah terkumpul, tanpa adanya kemungkinan dimintanya kembali bagiannya yang telah disetor ke PT.

4. Prinsip pengurus oleh suatu organ. Sebagai suatu modal, perseroan terbatas terdiri dari banyak-pemegang saham. Jumiah yang amat banyak dari pemegang saham tersebut tidak mungkin semuanya menjadi pengurus.

5. Persyaratan hukum Banyak dari hukum positif Indonesia mesyaratkan bahwa kegiatan usaha atau bisnis tertentu harus dilakukan oleh badan hukum Indonesia berbentuk PT.

Sri Rejeki Hartono mengemukakan, secara praktis alasan masyarakat banyak memilih kegiatan ekonominya menggunakan PT antara lain: ${ }^{5}$

1. Setiap jenis usaha yang mempunyai, jangkauan relatif luas, pada Ijin opraslonal selalu menyatakan bahwa perusahaan yang bersangkutan harus berbentuk badan hukum (pilihan utama pasti PT);

2. Setiap jenis usaha yang bergerak di bidang keuangan diisyaratkan dalam bentuk badan hukum.

Dapat dilihat dari beberapa unsur PT, alasan orang memilih PT sebagai wadah untuk mengembangkan kegiatan usaha mereka, maka salah satu alasan utama orang memilih wadah PT adalah karena unsur PT yang merupakan sebuah badan hukum yang mempunyai eksistensi sendiri selaku subjek hukum mandiri (persona standi in judicio). ${ }^{6}$ PT selaku subjek hukum mandiri memiliki konsekuensi mempunyai hak dan kewajiban yang terpisah dengan pendiri, anggota, atau penanam modal

\footnotetext{
4 Normin S. Pakpahan. 'Perseroan Terbatas Sebagai Instumen Kegiatan Ekonomi' (1997) 2 Jurnal Hukum Bisnis.[75].

5 Johari Santoso, 'Perseroan Terbatas sebagai Institusi Kegiatan Ekonomi yang Demokratis' (2000) 7 Jurnal Hukum.[197].

6 Machsun Tabroni, 'KesalahpahamanMaknaGugatan Perwakilan Kelompok dan Legal Standing di Indonesia' (2004) 11 Jurnal Hukum.[43].
} 


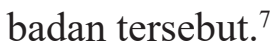

Dikarenakan PT merupakan sebuah persona standi in judicio, sehingga tidak bisa serta-merta PT tersebut lahir. Diperlukan beberapa prosedur tertentu, hingga berdirinya sebuah PT. Di Jakarta terdapat 11 prosedur dan terdapat 12 prosedur di Surabaya yang perlu dilakukan untuk berdirinya sebuah PT. Prosedut tersebut antara lain yaitu: (1) Pembayaran PNBP pesan/ pengecekan nama ; (2) Permohonan pesan nama; (3) Penyiapan akta pendirian perusahaan; (4) Pembayaran PNBP Pengesahan Badan Hukum PT; (5) Pengesahan badan hukum PT; (6) Pengajuan surat keterangan domisili perusahaan; (7) Pengajuan SIUP dan TDP; (8) Pendaftaran tenaga kerja perusahaan di Disnaker; (9) Permohonan NPWP dan NPPKP di KPP Pratama; (10) Pendaftaran kepesertaan BPJS Ketenagakerjaan; (11) Pendaftaran kepesertaan BPJS Kesehatan. ${ }^{8}$

Berdasarkan peringkat Ease Of Doing Business (selanjutnya disebut EODB) di Indonesia yang dikeluarkan oleh World Bank pada tahun 2017, untuk indikator starting a business dalam EODB tahun 20169, Indonesia menduduki peringkat 151 dari 189 negara. ${ }^{10}$ Berdasarkan hasil EODB 2017 tersebut, untuk memulai bisnis di Indonesia, rata-rata Kota Jakarta dan Surabaya, membutuhkan 11 prosedur, 24. ${ }^{9}$ hari, dan biaya 19.4\% dari pendapatan per kapita dan tidak membutuhkan syarat minimum modal usaha disetor. ${ }^{11}$ Proses yang masih memakan waktu adalah (1) Pengajuan SIUP dan TDP (Jakarta = 7 hari, Surabaya = 14 hari); dan (3) Pendaftaran BPJS Kesehatan (Jakarta \& Surabaya $=7$ hari) dan BPJS Ketenagakerjaan (Jakarta $\&$ Surabaya $=7$ hari $).{ }^{12}$

7 Purbandari, 'Tanggung Jawab Hukum Perseroan Terbatas (Pt) Yang Dinyatakan Pailit' (2014) 1 WidyaYustitia.[31].

8 EODB Indonesia, 'Starting Business adalah proses kegiatan pengurusan berbagai perizinan yang perlu dilakukan untuk memulai usaha Kecil dan Menengah.' (EODB Indonesia, 2018) < http://eodb.ekon.go.id/indikator-eodb/starting-a-business/>.

9 Peringkat EODB yang dikeluarkan oleh World Bank adalah hasil evaluasi untuk 1 tahun sebelumnya, missal peringkat yang dikeluarkan pada tahun 2016 adalah hasil evaluasi EODB pada tahun 2015, peringkat yang dikeluarkan pada tahun 2017 adalah hasil evaluasi EODB pada tahun 2016, dan seterusnya

${ }^{10}$ World Bank, Doing Business 2017: Equal Opportunity for All (World Bank 2017).[213].

11 ibid.

12 EODB Indonesia Loc.cit. 
Dalam rangka untuk menaikkan peringkat EODB di Indonesia, pemerintah mengambil kebijakan untuk mempermudah pendirian usaha di Indonesia, seperti mempermudah prosedur pendirian PT yang terejawantahkan dalam Paket Kebijakan Ekonomi XVI. ${ }^{13}$ Misalnya pada tahun 2018 pemerintah melakukan beberapa reformasi untuk mempermudah pendirian PT antara lain: ${ }^{14}$

\section{A. Biaya}

a) Merubah biaya pemesanan nama PT yang semula Rp 200.000 per permohonan menjadi Rp 100.000 per permohonan (PP No 45 Th 2016)

b) Merubah biaya pengesahan Badan Hukum PT sesuai PP No 45 Th 2016 dengan menyesuaikan biaya pengesahan dengan modal dasar yang sebelumnya Rp 1.000.000 per pengesahan untuk seluruh besaran modal, menjadi:

- $\operatorname{Rp} 200.000$ untuk modal dasar paling banyak Rp 25.000.000

- Rp 500.000 untuk modal dasar dari Rp 25.000.000 s.d Rp 1.000.000.000

- Rp 1.000.000 untuk modal dasar lebih dari Rp. 1.000.000.000

\section{B. Prosedur}

a) Penyatuan prosedur pendaftaran/pemesanan nama, pengajuan form pendirian, pengesahan dan pembayaran PNBP untuk pemesanan nama dijadikan satu. Prosesnya secara online lewat ahu.go.id;

b) Penggabungan pengurusan SIUP dan TDP dalam satu form secara simultan dengan biaya Rp 0,-. Untuk Jakarta melalui website www.pelayanan.jakarta. go.id untuk Surabaya melalui website www.ssb.surabaya.go.id;

c) Pendaftaran BPJS Kesehatan dan Ketenagakerjaan sekaligus di dalam 1 kali pendaftaran online melalui portal bersama BPJS. Khusus untuk DKI Jakarta, Pendaftaran BPJS Kesehatan sudah terintegrasi dengan pelayanan PTSP sehingga ketika perusahaan mengurus SIUP dan TDP secara simultan maka

\footnotetext{
13 Kementerian Koordinator Bidang Perekonomian Republik Indonesia,'Paket Kebijakan Ekonomi Minggu Ke-Iii November 2018 (Tahap XVI) ', (Kementerian Koordinator Bidang Perekonomian Republik Indonesia, 2018) ) https:/ekon.go.id/ekliping/download/4446/3060/ lampiran-paket-kebijakan-ekonomi-xvi-16-november-2018.pdf $>$.

${ }^{14}$ EODB Indonesia Op.cit.
} 
akan akan otomatis menjadi peserta BPJS Kesehatan.

Berikut tabel komparasi prosedur pendirian PT di Indonesia:

Tabel 1.1 Komparasi Prosedur Pendirian PT di Indonesia

\section{STARTING A BUSINESS}

Sebelum

Sesudah

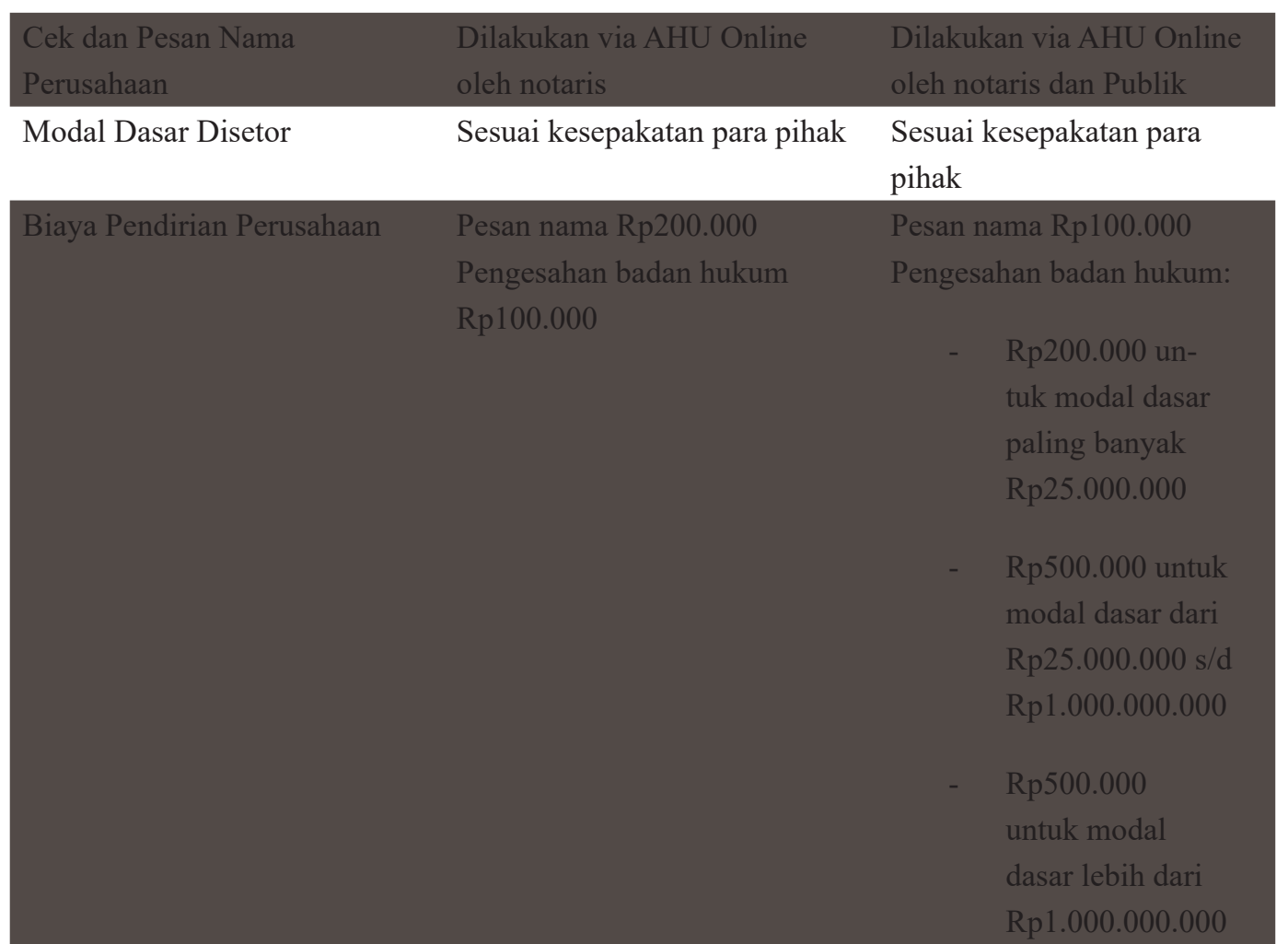

Pendaftaran BPJS Kesehatan

Pendaftaran BPJS

Ketenagakerjaan

Pengurusan SIUP \& TDP

Pendaftaran Tenaga Kerja ke

Disnaker
7 hari

7 hari

Dua prosedur terpisah

Satu prosedur terpisah

Dilakukan secara online

dalam satu formulir dan

website

Digabung menjadi satu

prosedur di PTSP

Prosedur digabung dalam pengajuang SIUP dan TDP di PTSP 


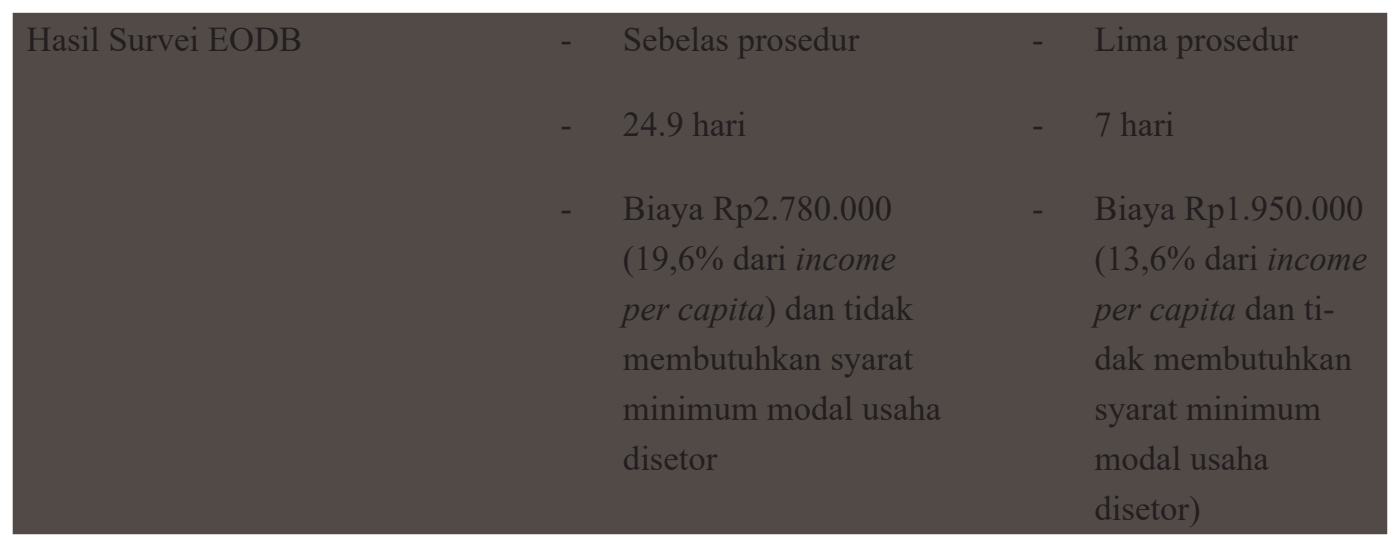

Sumber : http://eodb.ekon.go.id

Meskipun pemerintah terus berusaha mereduksi prosedur pendirian PT, namun masih terdapat beberapa prosedur yang diperlukan dalam mendirikan sebuah PT. Selama proses pendirian PT tersebut tidak menutup kemungkinan karena dirasa pendirian PT memakan waktu yang cukup lama, karena tidak sabar, maka para pendiri PT melakukan perbuatan hukum tertentu. Misalnya dalam proses pengesahan oleh Menteri Hukum dan HAM, para pendiri PT membuat kontrak dengan pihak ketiga atas nama PT.

Ketika PT yang belum berstatus badan hukum tersebut telah membuat kontrak dengan pihak ketiga, ada kalanya kontrak tersebut mengalami masalah. Dalam kondisi tersebut, pihak ketiga sering kali kebingungan terkait dengan siapa hubungan hukum tersebut terbentuk. Apakah hubungan hukum terjadi dengan PT ? Ataukah hubungan hukum tersebut masih berada pada para pihak yang membuat kontrak tersebut? Meningat pembuatan kontrak dilakukan sebelum PT tersebut memiliki status sebagai badan hukum, maka kontrak ini termasuk sebagai kontrak prainkorporasi. ${ }^{15}$ Kontrak prainkorporasi adalah kontrak yang dibuat oleh promotor sebelum PT menjadi badan hukum. ${ }^{16}$

Contoh terkait kontrak yang dibuat sebelum PT menjadi badan hukum ini adalah kasus PT. Bank Niaga v. Guardi Sunardi, Ny. Tan Seng Gwek, A. Hadrawi dan Ferdy Hardi Wijaya dalam Perkara No. 520 K/Pdt/1996. Dalam gugatannya

15 Muniar Fuady, Doktrin-Doktrin Modern dalam Corporate Law (PT Citra Aditya Bakti 2010).[152].

16 ibid. 
Penggugat meminta agar Pengadilan menyatakan Tergugat I, II, III dan Tergugat IV baik sendiri-sendiri maupun secara bersama-sama telah berhutang kepada Penggugat dari penerimaan fasilitas kredit pinjaman transaksi khusus sebesar Rp. 142.421.968,- dan menyatakan Tergugat I, II, III dan IV telah wanprestasi. ${ }^{17}$ Para tergugat mendalilkan bahwa, yang berhutang sejatinya adalah PT. Dharma Winarco, karena para pihak meminjam uang untuk PT Dharma Winarco, meskipun kontrak tersebut dibuat sebelum PT. Dharma Winarco berstatus badan hukum. Karena itu, para tergugat berpendapat, bahwa yang harus digugat adalah PT. Dharma Winarco dan bukan pribadi Tergugugat. Pengadilan Negeri Ujung Pandang dalam putusannya menyatakan, bahwa Tergugat I, II, III dan Tergugat IV baik sendiri-sendiri atau secara tanggung renteng membayar hutangnya kepada Penggugat. Namun, justru Putusan Pengadilan Tinggi Ujung Pandang tanggal 19 Oktober 1994 membatalkan Pengadilan Negeri Ujung Pandang Tersebut, dengan dalil bahwa perjanjian yang dibuat tersebut untuk kepentingan PT.Dharma Winarco, karena utang tersebut digunakan untuk kepentingan PT. Dharma Winarco. ${ }^{18}$

Berdasarkan contoh kasus tersebut menunjukan, masih belum adanya diferensiasi yang pasti terkait tanggung jawab dalam kontrak prainkorporasi ini. Bagaimanakah tanggung jawab para pendiri terhadap kontrak yang dibuat oleh PT tersebut, selain itu apabila PT tersebut telah mendapatkan status badan hukum, apakah hubungan hukum tersebut beralih kepada PT tersebut ? Bagaimanakah tanggung jawab PT tersebut terhadap perbuatan Direksi tersebut ? Bagaimana ketika pihak ketiga mengira membuat kontrak dengan PT yang telah memiliki status berbadan hukum, namun ternyata belum berstatus badan hukum.

Maka dari pertanyaan-pertanyaan yang muncul tersebut penulis tertarik untuk meneliti bagimana Tanggung Jawab Promotor Perseroan Terbatas Terhadap Kontrak Prainkorporasi dan mengenai penerapannya di dalam peraturan perundangundangan di Indonesia.

17 Yudi Hermawan, 'Kepailitan Perseroan Terbatas Yang Belum Berstatus Hukum' (2014), Tesis, Fakultas Hukum Universitas Diponegoro.[74].

18 ibid.[75]. 


\section{Konsep Promotor Dalam Perseroan Terbatas}

Istilah subjek hukum di kalangan ahli hukum tidak seragam. Ada yang menggunakan istilah purusa hukum (Oentari Sadino), awak hukum (St. K. Malikul Adil), pribadi hukum (Soerjono Soekanto, Purnadi Purbacaraka) dan sebagainya.19 Menurut Sudikno Mertokusumo, subjek hukum adalah segala sesuatu yang dapat memperoleh hak dan kewajiban dari hukum. ${ }^{20}$ Istilah subjek hukum berasal dari bahasa Belanda yaitu rechtsubject atau subject of law dalam bahasa Inggris. Secara umum rechtsubject diartikan sebagai pendukung hak dan kewajiban yaitu manusia (naturlijke person) dan badan hukum (rechtpersoon). ${ }^{21}$

Salah satu contoh badan hukum adalah PT. PT sebagai sebuah persona standi in judicio, memiliki konsekuensi yuridis, yaitu terpisah hak dan kewajibannya dengan para direksi, komisaris, dan para pemegang saham PT tersebut. ${ }^{22}$ Pemisahan hak dan kewajiban antara PT dengan para direksi, komisaris, dan para pemegang saham tersebut, tidak serta merta terjadi. Pemisahan ini baru terjadi ketika PT telah sah sebagai badan hukum. Sering kali para pengusaha sudah memulai melakukan kegiatan usaha, seperti membuat kontrak, tanpa memedulikan teknikalitas yuridis dari proses pendirian PT tersebut. Dari sinilah teori-tori hukum mengenai tanggung jawab promotor penting.

Definisi promotor PT adalah orang yang mendirikan, mengorganisasikan, dan membiayai suatu PT, tidak termasuk pihak professional yang membantu pembentukan PT, seperti pengacara atau notaris. ${ }^{23}$ Pihak professional yang semata-mata melakukan tugas-tugas klerikal dan adminsitratif ini dikenal sebagai inkorporator. ${ }^{24}$ Pihak inkorporator berbeda dengan promotor karena inkorporator tidaklah terlibat terlalu jauh dalam proses pendirian suatu PT, sehingga tanggung

\footnotetext{
${ }^{19}$ Chidir Ali, Badan Hukum (Alumni 2005).[14].

20 Sudikno Mertokusumo, Mengenal Hukum: Suatu Pengantar (Liberty 1988).[53].

21 Dyah Hapsari Prananingrum, 'Telaah Terhadap Esensi Subjek Hukum: Manusia Dan Badan Hukum', (2014) 8 Releksi Hukum. [74-78].

${ }^{22}$ Bambang Sutiyoso, 'Implementasi Gugatan Legal Standing dan Class Action dalam Praktik Peradilan di Indonesia' (2004) Jurnal Hukum 11.[72].

${ }_{23}$ Muniar Fuady, Doktrin-Doktrin Modern dalam Corporate Law (PT Citra Aditya Bakti 2010).[142].

${ }^{24}$ ibid.[144].
} 
jawabnya secara hukum juga limitatif. Umumnya, memang pihak inkorporator ini yang memproses pendirian suatu PT, namun hanya karena suatu perintah tertentu. Misalnya notaris/advokat yang mendapat pekerjaan untuk memproses pendirian PT.

Tidak menutup kemungkin para inkorporator ini secara temporal menjadi direksi atau komisaris,sampai kemudian diganti oleh direksi atau komisaris sesungguhnya yang lebih berkompeten. Para inkorporator ini dapat dimungkinkan untuk memegang saham, ataupun tidak. Dalam perkembangannya pihak inkorporator ini dapat dimungkinkan hanya seorang saja, meskipun masih ada beberapa Negara seperti Malaysia yang mewajibkan bahwa inkorporator berjumlah minimal dua orang dengan alasan bahwa PT adalah persekutuan modal, sehingga harus berasal dari antara 2 (dua) orang atau lebih. ${ }^{25}$

Disamping itu, dikenal pula istilah "founder" perseroan, yang dalam hal ini dapat disejajarkan dengan istilah "pendiri” dari suatu perseroan. istilah founder ini lebih bersifat umum. yang mencakup, baik pengertian "promotor" maupun pengertian "inkorporator".'istilah "founder" ini lebih digunakan dalam hal-hal sebagai berikut: ${ }^{26}$

1. Digunakan oleh umum-sehari-hari. Jadi, bukan merupakan istilah hukum; atau

2. Digunakan sebagai istilah hukum, di mana hukum di negara yang bersangkutan tidak memperbedakan antara pengertian "promoter." dan pengertian “inkorporator". seperti penggunaan istilah pendiri dalam sistem hukum lndonesia.

Kriteria yang menentukan bahwa seseorang dapat dikatakan promotor adalah dari faktor apakah dia memiliki keinginan agar PT didirikan, dan menyiapkan diri untuk mengambil langkah-langkah tertentu sebagai implementasi dari proses pendirian PT dengan atau tanpa bantuan pihak lainnya. Anggapan yang menilai bahwa seorang promotor PT adalah mereka yang terlibat dalam setiap tahap dalam proses pendirian PT tersebut adalah salah besar. Hal ini adalah sebuah kesalahan

${ }^{25}$ Malaysia Companies Act 1965 Section 14 ss (1) menyatakan jika perseroan dapat didirikan oleh dua orang atau lebih, lihat Nindyo Pramono et al., Karya Ilmiah Pelaksanaan Kegiatan Penulisan Karya Ilmiah Pusat Penelitian dan Pengembangan Sistem Hukum Nasional, (Badan Pembinaan Hukum Nasional Kementerian Hukum dan Hak Asasi Manusia R.I. 2012).[36].

${ }^{26}$ Munir Fuady Op.cit.[145]. 
konsep yang menyebabkan kesalahan kesimpulan, (ex falso quodlibet). ${ }^{27}$

Promotor sejatinya adalah setiap mereka yang melakukan formalitas yang diperlukan terhadap registrasi PT, mendapatkan direksi (dan komisaris) serta pemegang saham untuk PT baru, mendapatkan asset bisnis untuk digunakan oleh PT, melakukan negosiasi kontrak untuk dan atas nama PT baru, dan melakukan pekerjaan-pekerjaan lain serupa itu. Sehingga ketika promotor harus orang yang benar-benar terlibat dalam setiap tahap dalam proses pendirian PT, maka pendapat tersebut sangat mengkerucutkan konsep promotor sebuah PT. ${ }^{28}$ Misalnya dalam sejarah hukum PT, pada tahun 1877, dalam kasus Twycross vs Grant (Inggris), seorang promotor terlihat dari orang yang bertanggung jawab untuk mendirikan PT dalam hubungan dengan proyek tertentu dan meproses pelaksanaanya, serta mengambil langkah-langkah yang diperlukan untuk mencapai maksud tersebut., meski orang tersebut tidak terlibat dari awal suatu PT berdiri. Adapun yang merupakan tugas promotor antara lain adalah: ${ }^{29}$

\section{A. Kewajiban Pengurusan Pendirian PT}

Dalam hal ini pihak promotor berkewajiban untuk menyelesaikan proses hukumdan administrasi pendirian PT sampai PT telah menjadi badan hukum dan telah terbentuk perangkat hukum berupa pranata direksi. Direksi akan mengambi ahli tugas dari promotor dan sejak saat itu tugas promotor PT telah berakhir. Mengenai tempus terkait kapan suatu PT dapat dikatakan telah menjadi badan hukum, terdapat beberapa teori tertentu. Menurut teori yang bersifat objektif, seperti teori "konsensi" melihat bahwa suatu PT dianggap berdiri secara sah ketika mendapat semacam "konsensi" dari pemerintah.

Dalam perkembangannya, tidak semua Negara menganut teori "konsensi” tersebut secara ketat. Di Amerika Serikat misalnya, sejak tahun 1811 pihak pelaku bisnis dapat mendirikan PT tanpa perlu meminta izin dari pemerintah. Praktik ini berkembang seiring

27 Paul Lorenzen, Uber das Prinzip “ex Falso Quodlibet.” (1954) 19 J.Symbolic Logic .[298].

\footnotetext{
28 Mayson et al., Mayson on Revenue Law (Oxford 1990).[549].
}

${ }^{29}$ Muniar Fuady Op.cit.[148]. 
dengan berlakunya teori "perseroan de facto" yang menekankan pada "maksud" dari para pihak untuk membentuk suatu PT. Dalam hal ini, persoalan mendirikan PT dianggap sebagai urusan para pendiri PT, bukan urusan pemerintah. Intervensi pemerintah memang masih ada, namun terlimitasi hanya kepada ketentuan administrasi, seperti menyediakan file-file tertentu. Hal ini dikenal sebagai system filling (filling system).

Meskipun peran pemerintah hanya dalam hal urusan-urusan yang bersifat administratif, namun formalitas yang disyaratkan dalam proses pendirian sebuah PT tetap mempunyai kedudukan yang esensial. Hal ini disebabkan terdapat konsekuensi hukumnya yang serius jika syarat administratif tersebut tidak dipenuhi, yaitu proses pendirian PT dianggap cacat, sehingga PT dianggap tidak pernah ada, dengan konsekuensi pembebabanna tanggung jawab pihak promotor.

\section{B. Kewajiban Pendanaan}

Kewajiban pendanaan adalah salah satu kewajiban dari promotor. Dalam hal ini promotor dapat memperoleh sumber dana dari berbagai pihak untuk kepentingan jalannya PT. Sumber dana tersebut terdiri atas:

a) Pemasukan dari pemegang saham/investor sebagai harga sahamnya

b) Pinjaman dari pihak luat PT

c) Pinjaman dari pihak supplier yang menyuplai bahan-bahan keperluan PT

d) Pinjaman Subordinasi dari pemegang saham

\section{Kewajiban Pengaturan Bisnis}

Pihak Promorot juga mempunyai kewajiban pengaturan bisnis, khususnya pengaturan bisnis pada tahap-tahap awal pendirian PT, sebelum kemudian kewajiban ini diambil alih oleh direksi PT. Kewajiban mengatur dan menata bisnis ini, antara lain adalah:

a) Melakukan formulasi dan proposal untuk berbisnis;

b) Mendapatkan kesempatan berbisnis;

c) Mendapatkan mesin-mesin untuk beproduksi;

d) Melakukan pemasaran terhadap produk yang akan dihasilkan oleh PT;

e) Mendapatkan sumber-sumber bahan baku untuk kegiatan PT;

f) Mendapatkan agen dan supplier untuk memasarkan produk yang dihasilkan;

g) Membuat kontrak untuk dan atas nama PT yang akan terbentuk;

h) Mencari tenaga kerja untuk PT;

i) Mencari lokasi dan sekaligas membangun kantor, pabrik,dan lain sebagainya yang diperlukan bagi PT. 


\section{D.Kewajiban tentang Pendirian PT}

Kewajiban lain dari pihak promotor adalah kewaiban untuk memproses pendiriaan PT. Namun, dalam hal ini fungsi promotor bersatu dengan inkorporator. Namun, dalam hal incorporator adalah juga pihak promotor, maka kewajibannya juga menjadi bersatu.

\section{Tanggung Jawab Promotor Dalam Perseroan Terbatas}

Dalam konsep hukum terdapat 2 (dua) pengertian tentang tanggung jawab, yang memiliki perbedaan konsep, yaitu liability dan responsibility. ${ }^{30}$ Dalam Black's Law Dictionary, dijelaskan mengenai definisi liability yaitu the quality, state, or condition of being legally obligated or accountable; legal responsibility to another or to society, enforceable by civil remedy or criminal punishment. ${ }^{31}$ Jika diterjemahkan memiliki makna kualitas atau keadaan yang secara hukum diwajibkan atau dipertanggungjawabkan; tanggung jawab hukum kepada orang lain atau masyarakat, dilaksanakan melalui upaya hukum perdata atau pidana. Sementara definisi dari responsibility yaitu the quality, state, or condition of being answerable or accountable. Artinya adalah kualitas atau keadaan yang menjadi suatu tanggungjawab atau dapat dipertanggungjawabkan.

Dari sini dapat kita lihat bahwasanya pembedaan istilah tanggung jawab dengan tanggung gugat sangat dipengaruhi dengan pembedaan istilah responsibility dengan liability dalam kepustakaan berbahasa Inggris. Tanggung jawab seolah dipadankan dengan responsibility sedangkan tanggung gugat dipadankan dengan liability. ${ }^{32}$

MenurutPeter Mahmud Marzuki, tanggung gugat(liability/aansprakelijkheid) merupakan bentuk spesifik dari tanggung jawab. Pengertian tanggung gugat merujuk

\footnotetext{
${ }^{30}$ Meivy Insovania dan Suhandi, ‘Tanggung Jawab Dari Tanggung Gugat Hukum Pengobatan Alternatif Akupuntur’ (2006) 11 Perspektif.[155]. [1053].

31 Bryan A. Garner, Black's Law Dictionary, 10th Edition (St.Paul - Minnessota 2014).

32 Paulus Aluk Fajar Dwi Santo, 'Mempertanyakan Konsepsi Tanggung Gugat', <business-law binus 2016) http://business-law.binus.ac.id/2016/05/31/mempertanyakan-konsepsi-tanggung-gugat/> dikunjungi pada tanggal 31 Januari 2019.
} 
kepada posisi seseorang atau badan hukum yang dipandang harus membayar suatu bentuk kompensasi atau ganti rugi setelah adanya peristiwa hukum. Istilah tanggung gugat spesifik berada dalam ruang lingkup hukum privat. ${ }^{33}$

Terkait dengan konsep tanggung jawab promotor suatu PT ini, konsep hukum yang digunakan bukan hanya tanggung gugat (liability), namun juga tanggung jawab (responsbility), sehingga yang bisa dimintakan kepada promotor PT, tidak menutup kemungkinan hanya tanggung gugat (liability), yang bersifat keperdataan, namun dapat dimungkinkan dimintakan tanggung jawab (responsibility) yang sifatnya merupakan pidana.

Tanggung jawab yang lahir kepada para promotor PT ini timbul karena konsekuensi yuridis dari prinsip-prinsip hukum yang dianut oleh PT. Prinsip hukum tersebut antara lain:

\section{A. Tanggung jawab berdasarkan prinsip fiduciary duty.}

Dalam Black's Law Dictionary, dijelaskan mengenai konsep fiduciary duty adalah $A$ duty to act for someone else's benefit, while subordinating one's personal interests to that of the other person. It is the highest standard of duty implied by law (e.g. trustee, guardian). ${ }^{34}$ Seseorang dikatakan memiliki fiduciary capacity ketika bisnis yang ditransiaksikannya bukan miliknya, melainkan milik orang lain, di mana orang lain tersebut mempunyai kepercayaan yang besar kepadanya. Sehingga orang yang menjalankan bisnis tersebut wajib mempunyai itikad baik dalam menjalankan tugasnya tersebut.

Promotor PT yang mendapatkan kepercayaan untuk mendirikan suatu PT dari para pihak yang menitipkan modalnya, juga menjalankan prinsip fiduciary duty ini, di mana mereka wajib mengemban kepercayaan tersebut dengan melaksanakannya dengan itikad baik yang tinggi ( high degree of good faith). Pelanggaran terhadap fiduciary duty oleh promotor ini, misalnya ketika promotor tidak melakukan keterbukaan informasi terhadap tindakan-tindakan yang diwajibkan untuk disampaikan secara terbuka. Promotor memiliki fiduciary duty kepada para pihak dalam PT, seperti PT itu sendiri, pemegang saham,kreditor, dan sebagainya.

\footnotetext{
${ }_{33}$ Peter Mahmud Marzuki, Pengantar Ilmu Hukum (Kencana Prenada Media Group 2009).[258].

${ }^{34}$ Bryan A. Gamer Op.cit.[625].
} 


\section{B.Tanggung jawab berdasarkan prinsip-prinsip umum dalam hukum perdata}

Kepada pihak promotor tentunya juga dibebankan tanggung jawab berdasarkan hukum perdata terhadap hubungan hukum perdata antara pihak promotor dan pihak lain yang timbul karena:

- Pebuatan Melawan Hukum (onrechtmatige daad)

- Wanprestasi

Karena itu, setiap tindakan PT dengan suatu transaksi atau tidak yang menimbulkan kerugian bagi orang lain yang dilakukan oleh pihak promotor, pihak promotor harus memberi ganti kerugian sesuai hukum yang berlaku.Pihak-pihak yang berpotensi dirugikan antara lain:

- PT itu sendiri

Jika kerugian tersebut akibat tindakan promotor terhadap PT, maka PT mempunyai hak untuk menggugat kepada promotor agar mendapat ganti rugi dari tindakan promotor yang merugikan PT.

- Pemegang saham

Ketika tindakan promotor menimbulkan kerugian secara langsung kepada pemegang saham, maka pemegang saham juga mempunyai hak untuk mengajukan gugatan kepada promotor untuk mendapatkan ganti kerugian.

Dalam perkembangannya di praktik bisnis, promotor tidak selalu orang yang benar-benar telibat dalam kontrak/transaksi suatu PT, dimungkinkan promotor hanya memberi bantuan-bantuan terkait modal. Hal ini merupakan penyebab lahirnya diferensiasi dari promotor aktif dan pasif. Lahirnya diferensiasi baru ini juga menimbulkan masalah hukum baru, yaitu terkait sejauh mana pihak promotor pasif bertanggung jawab terhadap transaksi promotor aktif. Untuk menjawab hal tersebut, terdapat 2 (dua) teori yang dapat digunakan, yaitu: ${ }^{35}$

\section{A. Teori kemitraan}

Teori Kemitraan mengajarkan bahwa hubungan antara satu promotor dengan promotor lain merupakan suatu kemitraan, sehingga jika yang satu bertindak, maka

${ }^{35}$ Muniar Fuady Op.cit.[151-152]. 
yang lain juga ikut bertanggung jawab secara renteng (joint and several).

\section{B. Teori Keagenan}

Teori keagenan mengajarkan bahwa pihak promotor dalam membuat transaksi bertindak sebagai agen bagi PT yang akan terbentuk sehingga yang akan bertanggung jawab pada PT adalah agen itu sendiri jika PT tidak eksis ada akhirnya atau tidak meratifikasi tindakan promotor tersebut. Sehingga promotor pasif dianggap tidak ikut bertanggung jawab, karena tanggung jawab diberikan kepada promotor secara individu yang menjadi "agen" suatu PT, kecuali promotor pasif memberikan pengakuan untuk ikut bertanggung jawab. Pengakuan oleh promotor pasif tersebut dapat terlihat dari tindakan sebagai berikut:

- Promotor pasif ikut dalam transaksi dengan promotor aktif.

- Promotor pasif memberikan otorisasi terhadap tindakan tersebut.

- Promotor pasif ikut meratifikasi transaksi tersebut.

\section{Tanggung Jawab Promotor Perseroan Terbatas Terhadap Kontrak Prainkorporasi}

Berdasarkan tempus kontrak dibuat, maka kontrak dapat diklasifikasikan sebagai berikut :

a) Kontrak yang dibuat sebelum PT menjadi badan hukum (kontrak prainkorporasi);

b) Kontrak yang dibuat ketika PT telah menjadi badan hukum;

c) Kontrak yang dibuat setelah atau pada proses pembubaran PT. Kontrak yang dibuat oleh promotor sebelum suatu perseroan menjadi badan hukum ini dikenal sebagai kontrak prainkorporasi (pre-incorporaton agreement). Objek kontrak prainkorporasi antara lain: ${ }^{36}$

a) Kontrak bisnis PT yang dibuat oleh promotor untuk dan atas nama PT yang akan terbentuk;

b) Kontrak di antara pemegang saham potensial;

c) Kontrak antara para promotor dalam hubungan dengan pembentukan PT;

d) Kontrak pengambila bagian dari PT (share subscription);

e) Kontrak underwriting. 
Pada umumnya kontrak prainkorporasi akan mengikat para pihak promotor secara pribadi jika PT tidak meratifikasi kontrak yang bersangkutan. Akan tetapi, jika dilihat dari unsur mengikatnya, suatu kontrak prainkorporasi dapat diklasifikasikan sebagai berikut: ${ }^{37}$

1. Pihak promotor memperoleh opsi atau penawaran dari pihak ketiga kepada perseroan yang akan dibentuk, yang nantinya perseroan tersebut dapat menerima atau menolak kontrak yang bersangkutan.

2. Promotor membuat kontrak prainkorporasi bukan atas nama perseroan, melainkan atas namanya sendiri dan tanpa klasula yang mengikat perseroan.

3. Pihak promotor bertindak layaknya agen dalam membuat kontrak dengan pihak ketiga untuk dan atas nama perseroan yang akan dibentuk.

4. Pada waktu kontrak dibuat oleh promotor, kontrak tersebut sudah mengikat promotor, namun dengan ketentuan bahwa ketika perseroan telah terbentuk, kedudukan promotor digantikan oleh perseroan tersebut dan promotor dibebaskan dari tanggung jawab hukum.

5. Kontrak sudah mengikat promotor pada waktu kontrak dibuat promotor, namun dengan ketentuan bahwa ketika perseroan terbentuk dan meratifikasi kontrak, pihak promotor akan bertanggung jawab secara sekunder, yaitu sebagai garantor/sureties.

6. Kontrak sudah mengikat promotor pada waktu kontrak dibuat promotor, namun dengan ketentuan bahwa sebagai konsiderasi, pihak promotor berjanji akan melakukan upaya terbaik untuk memproses pendirian perseroan serta meratifikasikan kontrak prainkorporator.

7. Promotor membuat kontrak accessoir lain terpisah yang menentukan bahwa pihak ketiga setuju mengikat perseroan ketika perseroan terbentuk serta membiarkan penawaran kontrak tetap terbuka sampai terbentuknya perseroan.

Kriteria yang digunakan untuk menentukan pihak yang harus bertanggung jawab secara hukum terhadap transaksi prainkoprasi, antara promotor secara pribadi dengan PT antara lain:

1. Konstruksi kontrak yang bersangkutan;

2. Bahasa yang digunakan dalam kontrak tersebut;

3. Kesepakatan para pihak dalam kontrak tersebut.

Promotor dapat membuat kontrak dengan kemungkinan sebagai berikut :

1. Menerima penawaran dari pihak lain untuk dirinya sendiri yang akan diambil alih oleh PT setelah PT terbentuk;

${ }^{37}$ James D Cox et.al, Corporations (Introduction to Law) (Aspen Law \& Business 1997).[77]. 
2. Membuat kontrak yang semula mengikat promotor, tetapi dengan understanding yang jelas bahwa jika PT telah terbentuk, maka PT akan menggantikan posisi promotor dan akan membebaskan promotor dari tanggung jawabnya;

3. Kontrak mengikat promotor, tetapi promotor meminta penggantian (indemnity) dari PT.

Tentang konsekuensi yuridis terhadap kontrak prainkorproasi ini terdapat banyak teori yang menjelaskan mengenai konsekuensi yuridis dalam pembuatan kontrak prainkorporasi ini. Secara umum konsekuensi yuridis dari transaksi atau kontrak prainkorporasi adalah salah satu di antara kategori berikut:

1. Kontrak diratifikasi oleh PT sehingga menjadi sah dan mengikat penuh;

2. Kontrak tidak diratifikasi oleh PT dan kontrak menjadi batal demi hukum;

3. Kontrak tidak diratifikasi oleh PT, tetapi kontrak tersebut tetap sah, hanya yang bertanggung jawab adalah promotor secara indvidu atau secara tanggung renteng bile terdapat lebih dari 1 (satu) promotor.

Banyak terdapat banyak teori yang dapat digunakan untuk menjelaskan mengenai pihak yang bertanggung jawab dalam kontrak prainkorporasi. Hal ini bergantung pada konstruks dari kontrak prainkorporasi tersebut. Dimungkinkan promotor yang bertanggung jawab, dapat pula PT yang bertanggung jawab. Secara umum, faktor utama yang menentukan mengenai tanggung jawab tersebut adalah bila kontrak prainkorporasi tersebut diratifikasi oleh PT tersebut. Walaupun di beberapa negara terdapat berbagai variasi akan pegaturanya.

Contoh terkait tanggung jawab kontrak prainkorporasi misalnya di Inggris. Konsep hukum Inggris menyatakan bahwa dengan ratitikasi oteh PT, pihak PT tidak menjadi pihak dalam kontrak tersebut, tetapi pihak PT bertanggung jawab secara hukum terhadap manfaat yang diterima oleh PT terhadap kontrak yang bserangkutan. ${ }^{38}$ Namun, lain halnya dengan sistem hukum yang berlaku di Amerika Serikat, di mana seteiah PT meratifikasi kontrak prainkorporasi, PT dapat menjadi

\footnotetext{
${ }^{38}$ Muniar Fuady Op.cit.[157].
} 
pihak dalam kontrak tersebut sehingga pihak PT bertanggung jawab secara hukum terhadap kontrak tersebut secara keseluruhan, bukan hanya terhadap mantaat yang diperoleh perseroan dari kontrak yang bersangkutan. ${ }^{39}$ Sebaliknya, di Amerika, meskipun PT telah mendapatkan manfaatnya dari kontrak prainkorporasi, hal tersebut secara hukum belumlah cukup untuk mengikat perseroan terhadap kontrak yang bersangkutan. Walaupun dalam hal seperti itu jika perseroan tidak dianggap tatah meratifikasi kontrak tersebut, PT harus mengganti senilai mantaat yang telah diterimanya datam bentuk quantum meruit ${ }^{40}$.

\section{Penerapan Tanggung Jawab Promotor Perseroan Terbatas Terhadap Kontrak Prainkorporasi di Indonesia}

Secara teoritis di Indonesia dikenal dua kelompok badan usaha, yaitu badan usaha yang berbadan hukum dan badan usaha bukan badan hukum. ${ }^{41}$ Badan usaha berbadan hukum memiliki karakteristik yang berbeda dengan badan usaha bukan badan hukum. PT digolongkan sebagai badan hukum berdasarkan pasal 1 angka 1 Undang-Undang Nomor 40 Tahun 2007 tentang Perseroan Terbatas (selanjutnya disebut UUPT). PT sebagai badan hukum harus memenuhi beberapa unsur badan hukum yaitu: ${ }^{42}$

a. organisasi yang teratur; berdasarkan pasal 1 angka 2 UU PT, PT harus memiliki organ, yaitu RUPS, direksi, dan dewan komisaris.

b. memiliki harta kekayaan sendiri; modal PT harus dari harta kekayaan sendiri yang terpisah.

c. melakukan hubungan hukum sendiri;

PT sebagai badan hukum dapat melakukan hubungan hukum diwakili oleh pengurusnya.

d. mempunyai tujuan sendiri;

PT bertujuan untuk mencari keuntungan (profit oriented).

39 ibid.

${ }^{40}$ Quantum Meruit adalah sebuah doktrin hukum di mana tidak seorang pun dapat diuntungkan oleh kerja keras dan materi orang lain, sehingga orang tersebut dapat diperkaya secara tidak adil , lihat G. H. L. Fridman,' Quantum Meruit' (1999) 37 Alberta Law Review.[38].

${ }^{41}$ Nindyo Pramono Op.cit.[13].

42 Abdul Kadir Muhammad, Hukum Perusahan Indonesia (PT Citra Aditya Bakti 2002).[69]. 
Perbedaan karakteristik antara badan usaha berbadan hukum dan badan usaha bukan berbadan hukum mengakibatkan perbedaan tanggung jawab. Perbedaan ini disebabkan karena tidak semua badan usaha merupakan subjek hukum. Saat ini, subjek hukum tidak hanya meliputi perorangan (natuurlijk persoon), namun hukum juga mengakui badan hukum (rechtspersoon) sebagai subjek hukum. ${ }^{43}$ Sehingga, badan usaha yang berbadan hukumlah yang dapat melakukan tindakan hukum.

Berdasarkan pasal 7 ayat (4) UU PT yang menyatakan bahwa PT memperoleh status badan hukum pada tanggal diterbitkannya Keputusan Menteri Hukum dan Hak Asasi Manusia mengenai pengesahan badan hukum PT, maka PT tidak serta merta disebut badan hukum, meskipun pada pasal 1 angka 1 UU PT menyatakan bahwa perseroan terbatas adalah badan hukum. PT yang belum mendapat pengesahan tidak bisa melakukan perbuatan hukum sendiri. Ketika suatu PT belum mendapat pengesahan sebagai badan hukum, maka yang dapat melakukan tindakan hukum adalah perseorangan atau pendiri PT tersebut, bukan perseroan terbatas itu sendiri. Demikian, tanggung jawab ketika terjadi kerugian terhadap pihak ketiga juga tidak dapat disamakan dengan PT sebagai badan hukum.

Seperti yang telah dijelaskan sebelumnya, bahwa promotor adalah seseorang yang memutuskan untuk membentuk perusahaan untuk tujuan tertentu dalam menjalankan bisnisnya yang sudah ada atau memulai yang baru yang dalam perusahaan tersebut ia adalah pemegang saham. ${ }^{44} \mathrm{Di}$ Indonesia istilah promotor dan inkorporator tidak dibedakan. Dalam UU PT hanya dikenal istilah pendiri perseroan terbatas. Sehingga di Indonesia, istilah pendiri dapat berarti promotor dan inkorporator. ${ }^{45}$

Berdasarkan pasal 7 ayat (1) UU PT, pendirian PT umumnya mensyaratkan minimal dua pendiri, yang berarti juga dibutuhkan minimal dua promotor, kecuali untuk perseroan terbatas yang tergolong pada pasal 7 ayat (7) UU PT. Pasal 7 ayat (2) UU PT menyatakan bahwa setiap pendiri PT wajib mengambil bagian saham

\footnotetext{
${ }^{43}$ Dyah Hapsari Prananingrum, Op.Cit. [5].

44 Agbonika dan John Musa Alewo, 'The Rising Profile of a Promoter in the Life of A Company: The Nigerian view point', (2014) 27 Journal of Law, Policy and Globalization. [111].

${ }^{45}$ Muniar Fuady Op.cit.[181].
} 
pada saat perseroan terbatas didirikan, sehingga pendiri perseroan terbatas dalam hal ini juga merupakan pemegang saham perseroan. Namun perlu diketahui bahwa ada kalanya nama pendiri yang nyatanya tercantum di akta pendirian perseroan terbatas bukanlah promotor melainkan pendiri bayangan atau dummy incorporator. UU PT tidak memberikan perbedaan antara promotor dan dummy incorporator, semua digolongkan sebagai pendiri perseroan terbatas yang nantinya wajib menjadi pemegang saham dalam perseroan terbatas tersebut.

Umumnya, pendiri sebagai pemegang saham bertanggung jawab secara terbatas hanya pada saham yang dimiliki karena PT adalah badan hukum. Hal ini sesuai yang termaktub pada pasal 3 ayat (1) UU PT yang menyatakan bahwa pemegang saham perseroan tidak bertanggung jawab secara pribadi atas perikatan yang dibuat atas nama perseroan terbatas dan tidak bertanggung jawab atas kerugian perseroan terbatas melebihi saham yang dimiliki. Namun, ketika PT tersebut belum merupakan badan hukum sesuai pasal 7 ayat (4) UU PT, maka pasal 3 ayat (1) UU PT tersebut tidak berlaku. Hal ini dapat dicermati pula pada pasal 3 ayat (2) huruf a UU PT yang menyatakan bahwa ketentuan sebagaimana dimaksud pada ayat (1) tidak berlaku apabila persyaratan perseroan terbatas sebagai badan hukum belum atau tidak terpenuhi. Demikian, jika pasal 3 UU PT ditafsirkan secara a contrario, maka pendiri yang merupakan pemegang saham bertanggung jawab secara pribadi atas perikatan yang dibuat atas nama perseroan terbatas sebelum perseroan terbatas mendapat pengesahan sebagai badan hukum.

Tanggung jawab yang dibebankan secara pribadi dan tak terbatas terhadap para pendiri PT merupakan konsekuensi logis dari belum berdirinya PT sebagai badan hukum yang merupakan subjek hukum. PT yang telah disahkan sebagai badan hukum sejak saat itu menjadi subjek hukum yang mampu mengemban hak dan kewajiban serta mampu untuk bertanggung jawab secara mandiri terhadap segala akibat yang timbul atas perbuatan yang dilakukan. ${ }^{46}$ Namun, perbuatan hukum para pendiri PT sejatinya dapat mengikat atau berakibat hukum pada perseroan terbatas

${ }^{46}$ Varly Verari Maneking,' Kedudukan Hukum dan Tanggung Jawab Pendiri Perseroan Terbatas Menurut Undang-Undang Nomor 40 Tahun 2007', (2016) 5 Lex Crimen. [92]. 
setelah PT tersebut disahkan menjadi badan hukum. Perbuatan hukum tersebut dapat menimbulkan hak dan kewajiban serta mengikat perseroan terbatas yang berbadan hukum jika dinyatakan secara tegas dan tertulis dalam akta pendirian atau RUPS pertama perseroan terbatas yang secara tegas menyatakan hal tersebut. Hal ini termaktub dalam pasal 12 jo. pasal 13 jis. pasal 14 UU PT.

Setelah PT telah didirikan dengan akta pendirian namun belum mendapat pengesahan sebagai badan hukum, maka ada kepemilikan bersama yang bersifat mengikat, sebagai akibat dari pendirian perseroan terbatas dan hal ini dapat disamakan kedudukannya dengan suatu firma.47 Tujuan firma dan perseroan terbatas memiliki kesamaan yaitu mencari keuntungan. Persekutuan disebut firma apabila mengandung unsur-unsur pokok sebagai berikut:48

1. Persekutuan perdata;

2. Menjalankan perusahaaan;

3. Dengan nama bersama; dan

4. Tanggung jawab sekutu bersifat pribadi untuk keseluruhan.

Apabila dianalogikan seperti firma, maka berdasarkan pasal 18 Kitab Undang-Undang Hukum Dagang (KUHD), tanggung jawab sekutu, yang dalam hal ini adalah para pendiri yang melakukan perbuatan hukum untuk dan atas nama PT yang belum berbadan hukum, merupakan tanggung renteng. Hubungan para promotor yang memiliki tanggung jawab secara tanggung renteng tersebut berkoherensi dengan teori kemitraan. Teori ini pun dituangkan dalam pasal 14 UU PT, yang pada pasal 14 ayat (1) UU PT menyatakan bahwa perbuatan hukum atas nama perseroan terbatas yang belum memperoleh status badan hukum, hanya boleh dilakukan oleh semua anggota Direksi bersamasama semua pendiri serta semua anggota Dewan Komisaris perseroan terbatas dan mereka semua bertanggung jawab secara tanggung renteng atas perbuatan hukum tersebut.

\footnotetext{
47 ibid. [94].

48 Gibran Mohammad, 'Pertanggungjawaban Firma Hukum Terhadap Kerugian yang Diderita Oleh Konsumen Jasa Hukum (Klien) dalam Pemberian Jasa Hukum’ (2018) Skripsi, Fakultas Hukum Universitas Lampung.[27].
} 
Tanggung renteng pada pasal 14 ayat (1) UU PT muncul tidak hanya dengan istilah pendiri, namun juga Direksi dan Dewan Komisaris. Ratio legis pada pasal $a$ quo sesungguhnya dapat dilihat pada penjelasan pasal a quo, yaitu bertujuan agar anggota direksi tidak dapat melakukan perbuatan hukum atas nama perseroan yang belum memperoleh pengesahan badan hukum oleh Menteri Hukum dan Hak Asasi Manusia tanpa persetujuan pendiri, anggota Direksi lainnya dan Dewan Komisaris. Sedangkan, perihal mengenai kedudukan perbuatan pendiri perseroan terbatas yang dilakukan sebelum adanya pengesahan sebagai badan hukum dipertegas pada pasal 14 ayat (2) UU PT yang menyatakan bahwa perbuatan hukum oleh pendiri sebelum perseroan terbatas berbadan hukum merupakan tanggung jawab pendiri yang bersangkutan dan tidak mengikat perseroan terbatas tersebut. Pasal a quo semakin menunjukkan bahwa pada hakikatnya promotor bertanggung jawab akan segala kerugian yang disebabkan oleh perbuatan hukumnya sebelum PT berbadan hukum.

Tanggung jawab tersebut muncul karena adanya akibat hukum dari perbuatan hukum para promotor sebelum PT tersebut menjadi badan hukum. Kerugian yang disebabkan oleh kesalahan para promotor sebelum perseroan terbatas berbadan hukum harus dipertanggungjawabkan kepada para promotor selaku pemangku hak dan kewajiban hukum. Tanggung jawab dapat timbul baik dari perbuatan melawan hukum maupun wanprestasi, maupun dalam ranah hukum publik. Ganti rugi sebagai bentuk tanggung gugat para promotor dapat ditujukan terhadap siapa saja yang telah dirugikan oleh para promotor. Pihak-pihak yang berpotensi dirugikan oleh para promotor tersebut adalah kreditor, pemegang saham, bahkan PT itu sendiri.

PT yang telah menjadi badan hukum dapat menggugat para promotornya bila tindakan dari para promotor sebelum PT berbadan hukum nyatanya menimbulkan kerugian bagi PT yang bersangkutan. Ketika menjadi badan hukum, RUPS perseroan terbatas tersebut diberi diskresi untuk menentukan perbuatan para promotor termasuk dalam perbuatan perseroan terbatas tersebut atau tidak sesuai dengan pasal 13 ayat (1) UU PT. Demi kepentingan perseroan terbatas, secara logis RUPS tidak akan menyetujui perbuatan promotor yang merugikan PT, yang dalam hal ini adalah pembuatan kontrak prainkorporasi. Sebagai subjek hukum, badan 
hukum dapat digugat atau menggugat di pengadilan. ${ }^{49}$ Sehingga, upaya hukum yang dapat diambil PT berbadan hukum demi kepentingan PT itu sendiri adalah gugatan perbuatan melanggar hukum (onrechtmatige daad) berdasarkan pasal 1365 BW terhadap promotor. Namun, perlu dicermati bahwa diskresi RUPS semacam ini hanya timbul ketika belum disepakati secara tertulis oleh para pendiri sesuai pasal 13 ayat (5) UU PT.

Selain PT, jika pembuatan kontrak prainkorporasi oleh promotor tersebut menimbulkan kerugian secara langsung terhadap pemegang saham, maka pemegang saham juga memiliki hak mengajukan gugatan untuk mendapatkan ganti rugi dari promotor tersebut. ${ }^{50}$ Hak untuk mengajukan gugatan oleh pemegang saham atas tindakan hukum promotor atas nama perseroan sebelum perseroan menjadi badan hukum berakar dari adanya pasal 1365 BW. UU PT tidak mengatur hak pemegang saham untuk menggugat promotor tersebut. Pasal 61 ayat (1) UU PT hanya mengatur mengenai hak menggugat setiap pemegang saham terhadap PT ke pengadilan negeri apabila dirugikan karena tindakan perseroan terbatas yang dianggap tidak adil dan tanpa alasan wajar sebagai akibat keputusan RUPS. Perihal penggugatan promotor oleh pemegang saham, tetap harus mengingat akan adanya pasal 12 jo. pasal 13 jis. pasal 14 UU PT, ketika telah menjadi perbuatan PT yang telah berbadan hukum, maka perbuatan tersebut sudah mengikat PT itu, bukan para promotor. Hal ini berkaitan dengan limited liability yang dimiliki personil perseroan. ${ }^{51}$ Ketika PT yang melakukan perbuatan melanggar hukum, maka PT tersebut yang bertanggung jawab atas perbuatannya ${ }^{52}$

Gugatan yang dilayangkan oleh pemegang saham akibat perbuatan promotor sebelum PT berbadan hukum lahir dari kenyataan bahwa PT merupakan persekutuan

${ }^{49}$ Hapip Malik, Analisis tentang Pertanggungjawaban Pidana di dalam Kejahatan Korporasi, (2016) Skripsi, Fakultas Hukum Universitas Muhammadiyah Malang.[1].

${ }^{50}$ Muniar Fuady Op.cit.[150].

51 Kementerian Hukum dan Hak Asasi Manusia, Naskah Akademik Rancangan UndangUndang tentang Perseroan Terbatas, (Kementerian Hukum dan Hak Asasi Manusia 2016).[66].

52 Nike K. Rumokoy, 'Pertanggungjawaban Perseroan Selaku Badan Hukum dalam Kaitannya dengan Gugatan atas Perseroan (Dengan Undang-Undang Nomor 40 Tahun 2007 tentang Perseroan Terbatas sebagai Acuan Pembahasan)' (2011) 19 Jurnal Hukum Unsrat.[14]. 
modal. Yang dimaksud persekutuan modal adalah bahwa modal dasar PT terbagi dalam sejumlah saham-saham yang pada dasarnya dapat dipindah tangankan (transferable shares). ${ }^{53}$ Setelah promotor sebagai pendiri wajib menjadi pemegang saham berdasarkan pasal 7 ayat (2) UU PT, promotor tersebut bebas untuk mengalihkan sahamnya kepada siapapun yang berkenan untuk membeli sahamnya. Demikian, gugatan pemegang saham terhadap promotor merupakan upaya hukum yang dapat ditempuh agar promotor tidak lepas dari tanggung gugatnya. Posibilitas pemegang saham yang dapat menggugat ganti rugi adalah sebagai berikut: ${ }^{54}$

a. pemegang saham yang dirugikan pada saat terjadi tindakan tersebut;

b. pemegang saham lain yang mendapat saham dari pemegang saham yang dirugikan pada saat terjadi tindakan merugikan;

c. pemegang saham yang dirugikan yang mendapatkan saham langsung dari perseroan; dan/atau

d. pemegang saham yang dirugikan yang mendapatkan sahamnya langsung dari promotor.

Promotor juga harus bertanggung gugat akan segala perikatan yang dibuatnya terhadap pihak ketiga, dalam hal ini adalah kreditor. Kreditor dapat melakukan gugatan baik atas dasar wanprestasi maupun perbuatan melawan hukum, bahkan ketika para promotor tidak melakukan fiduciary duty, misalnya tidak melakukan full disclosure. ${ }^{55}$ Meskipun promotor bertanggung jawab akan segala perikatan yang dibuatnya terhadap siapapun sebelum PT belum mendapat pengesahan badan hukum dari Kementerian Hukum dan Hak Asasi Manusia, perlu diingat bahwa tanggung jawab tersebut juga dapat beralih ke PT setelah menjadi badan hukum. Berdasarkan pasal 14 ayat (4) UU PT, perbuatan hukum promotor sebelum PT belum mendapat badan hukum menjadi tanggung jawab perseroan terbatas tersebut setelah menjadi badan hukum melalui prosedur persetujuan RUPS. RUPS yang dimaksudkan adalah RUPS pertama yang harus diselenggarakan paling lambat enam puluh hari setelah Perseroan memperoleh status badan hukum sesuai pasal

${ }^{53}$ Hiasinta Yanti Susanti Tan, 'Konsekuensi Perubahan Undang-Undang Perseroan Terbatas terhadap Eksistensi Perseroan Terbatas’ (2008) Tesis, Fakultas Hukum Universitas Diponegoro. [39].

${ }^{54}$ Muniar Fuady Op.cit.[151].

55 ibid. 
14 ayat (6) UU PT. Hal ini terjadi pada kasus putusan Pengadilan Negeri Sumbawa Besar Nomor 06/Pdt.G/2011/PN.SBB yang mengabulkan eksepsi tergugat bahwa terjadi error in persona, karena perbuatan hukum para pendiri telah beralih menjadi perbuatan hukum PT berdasarkan RUPS pertama, sehingga para tergugat seharusnya bukanlah para pendiri PT, melainkan perseroan terbatas itu sendiri. ${ }^{56}$

Tanggung jawab hukum para promotor yang dimaksud pada pasal 14 UU PT sesungguhnya tidak dibatasi hanya pada lingkup liability based on fault. Tanggung jawab tersebut tidak terpatok dari adanya perjanjian maupun kesalahan seperti dalam gugatan wanprestasi dan gugatan perbuatan melanggar hukum. Tanggung jawab tersebut dapat meliputi pula strict liability, yaitu tanggung jawab mutlak tanpa perlu pembuktian adanya unsur kesalahan (fault) ${ }^{57}$ Strict liability dapat ditemukan dalam hal kerugian yang berkaitan dengan lingkungan. Undang-Undang Nomor 32 Tahun 2009 tentang Perlindungan dan Pengelolaan Lingkungan Hidup hanya mengenal tanggung jawab mutlak dalam arti strict liability, sebagaimana ditegaskan dalam pasal $88 . .^{58}$

\section{Kesimpulan}

Tanggung jawab promotor terhadap kontrak prainkorporasi pada hakikatnya terletak pada promotor PT secara tanggung renteng sesuai dengan pasal 14 ayat (1) dan ayat (2) UU PT. Hal ini merupakan konsekuensi logis dari status PT belum mendapat pengesahan sebagai badan hukum, yang berarti pada saat dibuatnya kontrak, PT belum menjadi subjek hukum. Ketika PT bukan sebagai subjek hukum, PT tidak mengemban hak dan kewajiban hukum. Hal ini berarti PT tidak dapat melakukan perbuatan hukum dan tidak dimungkinan suatu PT yang tidak

${ }^{56}$ Hery Shietra, 'Tanggung Jawab Perdata Calon Pendiri Perseroan' (hukum-hukum 2017) $<$ https://www.hukum-hukum.com/2017/04/tanggung-jawab-perdata-calon-pendiri-perseroan. html>, dikunjungi pada tanggal 30 Januari 2019.

57 Andria Luhur Prakoso, 'Prinsip Pertanggungjawaban Perdata dalam Perspektif Kitab Undang-Undang Hukum Perdata dan Undang-Undang Nomor 32 Tahun 2009 tentang Perlindungan dan Pengelolaan Lingkungan Hidup', Prosiding Seminar Nasional “ Tanggung Jawab Pelaku Bisnis dalam Pengelolaan Lingkungan Hidup (Publikasi Ilmiah UMS 2016).[213].

${ }^{58}$ Sutoyo, 'Pengaturan Tanggung Jawab Mutlak (Strict Liability) dalam Hukum Lingkungan' (2011), 24 Jurnal Pendidikan Pancasila dan Kewarganegaraan.[64]. 
melakukan perbuatan hukum harus mengemban tanggung jawab.

Penyimpangan tanggung jawab terhadap adanya kontrak prainkorporasi yang dibuat promotor dapat dilakukan. Hal ini telah diatur dalam pasal $12 \mathrm{jo}$. pasal $13 \mathrm{jis}$. pasal 14 UU PT. Perbuatan hukum para promotor PT tehadap kontrak prainkorporasi dapat dialihkan menjadi perbuatan hukum PT setelah menjadi badan hukum melalui RUPS pertama atau telah disetujui sebelumnya secara tertulis oleh calon pendiri PT. Perbuatan hukum yang dialihkan tersebut tentunya juga mengakibatkan pengalihan tanggung jawab dari promotor kepada PT.

\section{Daftar Bacaan}

\section{Buku}

Abdul Kadir Muhammad, Hukum Perusahan Indonesia (PT Citra Aditya Bakti 2002).

Bryan A. Garner, Black's Law Dictionary, 10th Edition (St.Paul - Minnessota 2014).

Chidir Ali, Badan Hukum (Alumni 2005).

Gunawan Widjaja, Risiko Hukum Pemilik, Direksi \& Komisaris PT, Cetakan Pertama ( Forum Sahabat 2008).

James D Cox et.al, Corporations (Introduction to Law) (Aspen Law \& Business 1997).

Kementerian Hukum dan Hak Asasi Manusia, Naskah Akademik Rancangan Undang-Undang tentang Perseroan Terbatas (Kementerian Hukum dan Hak Asasi Manusia 2016).

Mayson et al., Mayson on Revenue Law (Oxford 1990).

Muniar Fuady, Doktrin-Doktrin Modern dalam Corporate Law (PT Citra Aditya Bakti 2010).

Nindyo Pramono et al., Karya Ilmiah Pelaksanaan Kegiatan Penulisan Karya Ilmiah Pusat Penelitian dan Pengembangan Sistem Hukum Nasional (Badan Pembinaan Hukum Nasional Kementerian Hukum dan Hak Asasi Manusia R.I. 2012).

Peter Mahmud Marzuki, Pengantar Ilmu Hukum (Kencana Prenada Media Group 
2009).

Sudikno Mertokusumo, Mengenal Hukum: Suatu Pengantar (Liberty 1988).

World Bank, Doing Business 2017: Equal Opportunity for All (World Bank 2017).

\section{Jurnal}

Agbonika dan John Musa Alewo, 'The Rising Profile of a Promoter in the Life of A Company: The Nigerian view point', (2014) 27 Journal of Law, Policy and Globalization.

Dyah Hapsari Prananingrum, 'Telaah Terhadap Esensi Subjek Hukum: Manusia Dan Badan Hukum', (2014) 8 Releksi Hukum.

Johari Santoso, 'Perseroan Terbatas sebagai Institusi Kegiatan Ekonomi yang Demokratis' (2000) 7 Jurnal Hukum.

Nike K. Rumokoy, 'Pertanggungjawaban Perseroan Selaku Badan Hukum dalam Kaitannya dengan Gugatan atas Perseroan (Dengan Undang-Undang Nomor 40 Tahun 2007 tentang Perseroan Terbatas sebagai Acuan Pembahasan)', (2011), 19 Jurnal Hukum Unsrat.

Normin S. Pakpahan. 'Perseroan Terbatas Sebagai Instumen Kegiatan Ekonomi' (1997) 2 Jurnal Hukum Bisnis.

Nunuk Listyowati,'Tanggung Jawab Hukum Perseroan Terbatas Yang Belum Berstatus Badan Hukum' (2015) 1 Spirit Pro Patria.

Machsun Tabroni, 'Kesalahpahaman Makna Gugatan Perwakilan Kelompok dan Legal Standing di Indonesia' (2004) 11 Jurnal Hukum.

Meivy Insovania dan Suhandi, 'Tanggung Jawab Dari Tanggung Gugat Hukum Pengobatan Alternatif Akupuntur' (2006) 11 Perspektif.

Paul Lorenzen, Uber das Prinzip “ex Falso Quodlibet." (1954) 19 J.Symbolic Logic.

Purbandari, 'Tanggung Jawab Hukum Perseroan Terbatas (Pt) Yang Dinyatakan Pailit' (2014) 1 WidyaYustitia.

Sutoyo, 'Pengaturan Tanggung Jawab Mutlak (Strict Liability) dalam Hukum Lingkungan', (2011), 24 Jurnal Pendidikan Pancasila dan Kewarganegaraan.

Varly Verari Maneking,' Kedudukan Hukum dan Tanggung Jawab Pendiri Perseroan 
Terbatas Menurut Undang-Undang Nomor 40 Tahun 2007', (2016) 5 Lex Crimen.

Yoahana, 'Tanggung Jawab Hukum Atas Bentuk Usaha Badan Hukum Dan Bentuk Usaha Non Badan Hukum' (2015) 8 Mecatoria.

Andria Luhur Prakoso, 'Prinsip Pertanggungjawaban Perdata dalam Perspektif Kitab Undang-Undang Hukum Perdata dan Undang-Undang Nomor 32 Tahun 2009 tentang Perlindungan dan Pengelolaan Lingkungan Hidup', Prosiding Seminar Nasional “ Tanggung Jawab Pelaku Bisnis dalam Pengelolaan Lingkungan Hidup (Publikasi Ilmiah UMS 2016).

Gibran Mohammad, 'Pertanggungjawaban Firma Hukum Terhadap Kerugian yang Diderita Oleh Konsumen Jasa Hukum (Klien) dalam Pemberian Jasa Hukum' (2018) Skripsi, Fakultas Hukum Universitas Lampung.

Hapip Malik, Analisis tentang Pertanggungjawaban Pidana di dalam Kejahatan Korporasi, (2016) Skripsi, Fakultas Hukum Universitas Muhammadiyah Malang.

Hiasinta Yanti Susanti Tan, 'Konsekuensi Perubahan Undang-Undang Perseroan Terbatas terhadap Eksistensi Perseroan Terbatas', (2008), Tesis, Fakultas Hukum Universitas Diponegoro.

\section{Laman}

EODB Indonesia, 'Starting Business adalah proses kegiatan pengurusan berbagai perizinan yang perlu dilakukan untuk memulai usaha Kecil dan Menengah.' (EODB Indonesia, 2018) < http://eodb.ekon.go.id/indikator-eodb/starting-abusiness/>.

Kementerian Koordinator Bidang Perekonomian Republik Indonesia,'Paket Kebijakan Ekonomi Minggu Ke-Iii November 2018 (Tahap XVI) ', (Kementerian Koordinator Bidang Perekonomian Republik Indonesia, 2018) ) https://ekon.go.id/ekliping/download/4446/3060/lampiran-paket-kebijakanekonomi-xvi-16-november-2018.pdf $>$.

Paulus Aluk Fajar Dwi Santo, 'Mempertanyakan Konsepsi Tanggung Gugat', $<$ business-law binus 2016) http://business-law.binus.ac.id/2016/05/31/ mempertanyakan-konsepsi-tanggung-gugat/>.

Hery Shietra, 'Tanggung Jawab Perdata Calon Pendiri Perseroan', (hukum-hukum, 2017) <https://www.hukum-hukum.com/2017/04/tanggung-jawab-perdatacalon-pendiri-perseroan.html>. 


\section{Perundang-undangan}

Undang-Undang Nomor 40 Tahun 2007 tentang Perseroan Terbatas (Lembaran Negara Republik Indonesia Tahun 2007 Nomor 106, Tambahan Lembaran Negara Republik Indonesia Nomor 4756).

Burgerlijk Wetboek.

HOW TO CITE: Xavier Nugraha dan Ave Maria Frisa Katherina, 'Tanggungjawab Promotor Perseroan Terbatas Terhadap Kontrak Prainkorporasi di Indonesia' (2019) Vol. 2 No. 1 Media Iuris. 